\title{
Comparative Studies of the Football Industries in China and Britain
}

\author{
Hongquan Li, Houzhong Jin \& Guoying Yuan \\ Sports Economics and Management School, Central University of Finance and Economics \\ Beijing 100081, China \\ E-mail: lihongquan22@163.com; jinhouzhong@126.com \\ Chuanchuan Kong, Yongmin Hua \& Li Lin \\ Beijing Sport University, Beijing 100084, China \\ E-mail: Kcc139@163.com
}

Received: January 28, $2011 \quad$ Accepted: February 20, $2011 \quad$ doi:10.5539/ijms.v3n2p157

\begin{abstract}
By the document literature method and the comparative analysis method, the successful experiences of the British football industry are summarized, and the problems existing in the Chinese football industry are analyzed in this article, and the research result will be used for references in relatively theoretical researches.

Keywords: Football industry, Organization

The football industry occupies large share in the physical industry, and it includes the football-in-itself industry, the peripheral industry, the agency industry, and the industrial consumers, and the football-in-itself industry is mainly embodied in entrance ticket, ad, TV broadcasting right, license and marketing of the products with the club mark, professional footballers' deal, and football lottery, and the peripheral industry and the football agency industry mainly include the manufacturing of football equipments, and the building of football field.
\end{abstract}

\section{Main Characteristics of the British Football Industry}

\subsection{Corporatization of Industrial Organization}

The entities (clubs and league matches) in the British football industry are the economic organizations which adopt the corporatization mode to operate commercially under the supervision of the football association. With the development of the football industry, the status and rights of the FA decrease day by day, and it only performs the management function to select and appoint the enforcement judge and maintain the industrial discipline. Its main function is to maintain the competitive balance and drive the development of the football industry by making regulations.

\subsection{Higher Barrier to Entry}

On the one hand, the England Professional Footballers' Association provides different products and digs the potential market demands through multi-level league matches system. On the other hand, it establishes the competitive balance mechanism to ensure the quality of product by the grading system and strengthening the competition among clubs. For the entry barrier, if there is one football league who wants to enter into the England market, it will face powerful entry barrier. For example, other three football associations in Britain will face large barrier when they want to enter into the England market. At present, in the whole Britain, there is only one powerful league, which is the important cause that the British football is so successful.

\subsection{Competition among Internal Organizations}

The competition among internal organizations in England football includes not only the competition among clubs, but also the competition among league matches. The competition among clubs is mainly embodied in footballers and entrance tickets, and the competition among league matches is wider. For example, the football league matches in England are supervised by the FA, but the English Premier League and the FA Cup all have the competition. Therefore, the competition among internal organizations has been one big characteristic in the British football industry, and with the development of the British football industry, the league matches become more and more diverse. 


\subsection{Weak Interference from Associations}

In England, the game operation and the rules of football are governed by two different organizations, because one organization could not play not only the role of footballer, but also the role of judge. Therefore, on the layer of the England Football League, it fully exerts its monopolized superiority, and obtains larger benefit in the negotiations with sponsors and TV media to enhance the overall treatments of all clubs. In addition, the corresponding associations' interference is weakened, and they can objectively and carefully make football rules and enhance the entertainment of games by the identity of exterior party.

\section{Main Characteristics of Chinese Football Industry}

\subsection{Weak Supervision and Frequent Scandals}

For any market, only the moral limitation is not effective. To strengthen the legislation and enforcement is the important measure to standardize the football market and reduce footballers and judges' immoral behaviors. From the commercial title sponsorship of "Marlboro Cup" introduced by the International Management Group in 1994 to that the Ministry of Public Security of China judicially surveyed the soccer fraud, soccer gamble, and black whistle in 2009, the football of China had experienced many big historical events such as "108 Sichuan fans chartered plane to support the team in Thailand" in 1995, the "breakthrough of judges' show" in 1998, the "Five Mouse in Serie B" in 2001, the "Beijing Guoan Striking" and the "G7 revolution" in 2004. In the initial of 2010, the routine vice-chairman of the Chinese Football Association was summoned, and in the Sep of 2010, the vice-chairman of the Chinese Football Association was also summoned, and many professional senior staffs were caught one after another. After 17 years' development, comparing with the English Premier league which started at the same time, the latter has been the most successful professional league matches in the world, but Chinese football has been the pronouns of soccer fraud, soccer gamble, black whistle, and insult.

\subsection{Excessive Power of Chinese Football Association}

In 2004, the Chinese Football Association Super League (CSL) was established by the Chinese Football Association with 16 clubs, and the Chinese Football Association invested 720 thousands Yuan, 36\% share of CSL, and other 16 clubs respectively invested 80 thousands Yuan, 4\% share of CSL. It is obvious that the CSL is absolutely controlled by the Chinese Football Association. At present, for the functions, the Chinese Football Association manages the sports achievements, and manages the competition market, and also manages the professional football, and in the development and operation of the professional football, it operates as the independent enterprise legal entity, with three identities including "officer", "civilian", and "dealer". The Chinese Football Association not only takes place the games, but also manages the games, and it is the intercessor in the games, and the actuality of the integration of government administration with enterprise induces that the government would excessively enter and interfere the professionally physical market, and the effective competition mechanism is hard to form in the physical market.

\subsection{Unreasonable Arrangement of League Matches}

Each sports competition season of British football goes beyond the year, which objectively makes for the game participated by the national team, and it will not disturb other important big games such as the World Cup and the Olympic Games. Furthermore, though the footballers who finish one season are tired, they have no worries about the rear and they can prepare the new games with all their strengths. But the league matches system of China is one sports competition season in each year, and when the national team participates in the World Cup, the league matches must be stopped, so the schedule of the league matches should be changed to accord with the international games, which is very important to keep the continuity of the league matches and recover footballers' strengths.

\subsection{Nonstandard Interior Management}

In system, quiet more clubs lack in definite standards to manage coaches and footballers, and the dispute often occurs because of unclear line between responsibility and right, impacting the normal running of clubs. In supervision, the relationships among clubs, government, enterprise, league matches, coaches, and footballers are not standard, with the limitation of legal system and legal references. In the management object, the professional management staffs are deficient. The success of professional sports mainly depends on the commercial operation including many professional systems such as finance, financing, marketing, and management, and these talents are just deficient in Chinese football.

\section{Conclusions}

In the development of the Chinese football industry, the Chinese Football Association should use the successful 
experience of British football for references, and make it become the unique coordinator in the professional football of China, and the power of the Chinese Football Association should be reduced, and the clubs should be operated by the corporate mode, and the Chinese Football Association should establish reasonable layers of league matches, dig the football market deeply, and establish the great mass-base to extend the league matches.

\section{References}

He, Shiquan, Wang, Linan \& Li, Wenhua. (2009). A Study on the Arrangement and Operation Mechanism of Professional Football League. Journal of Beijing Sport University, No. 10.

Jiang, Heping. (2010). Development Report of Chinese Physical Industry (2008-2010). Beijing: Social Sciences Academic Press. Jan. of 2010.

Liang, Jin \& Henry (Britain). (2004). Development Recitation of British Professional Football in Recent 10 Years: Economic View. Journal of Tianjin Institute of Physical Education, No. 1.

Liang, Yijun. (2010). Existing Problems in Innovation of Joint-stock of Professional Football Club in China. Journal of Sports and Science, No. 1.

Li, Xiaohui. (2008). Historical Evolvement of the Physical Industry in Developed Countries and Enlightenments for the Development of Chinese Physical Industry. Market Modernization, No. 16.

Simon Kuper \& Stephen Szymanski, interpreted by Ma, Rui. (2010). Football Economics. Beijing: China Light Industry Press. Jan. of 2010.

Stephen Dobson \& John Goddard, interpreted by Fan, Xiaoping \& Zhang, Jiye. (2004). Football Economics, Beijing: China Machine Press. Feb. of 2004.

Wang, Zhengzheng \& Zhang, Ning. (2009). Comparison and Analysis of the Football Industries in China and Britain. Inner Mongolia Sports Technology, No. 1.

Zhang, Jilong \& Fu, Hua. (2004). Crazy LEGA Serie A. Beijing: Guangming Daily Press. Nov. of 2004. 